\title{
The Potential of Bai Salam in Islamic Social Finance to Achieve United Nations' Sustainable Development Goals
}

\author{
Anggi Kusuma Putri \\ Esha tir Razia \\ Aishath Muneeza \\ International Centre for Education in Islamic Finance (INCEIF), \\ Malaysia
}

\begin{abstract}
Ending poverty is the first of the 17 goals of the 2030 Agenda for Sustainable Development set by the United Nations. The target is to have no more than 3 percent of the world's population living on just $\$ 1.90$ a day by 2030. A review on existing literature suggests that the United Nations need a more diverse approach to boost farming and alleviate poverty in order to meet its target. The paper is an effort to explore the possible application of an Islamic banking instrument in meeting the 2030 Agenda for Sustainable Development. This paper aims to explore the feasibility of Salam as an alternative mode of agricultural financing. The concept of the paper can be extended to non-farming industry especially the manufacturing industry. This paper describes the modus operandi of the proposed models, and identifies potential risks involved. Some recommendations are also given as risk mitigation methods.
\end{abstract}

Keywords: Islamic Finance; Poverty Alleviation; Salam; Sustainable Development Goals; United Nations 


\section{Introduction}

According to the United Nation (UN), nearly $10 \%$ of the world population live below the international poverty line (USD1.90 per day) and one of out of five children live in extreme poverty (United Nations, n.d.). Poverty exists in a vicious circle, impacting generation after generation. Issues such as limited or no access to education, poor health and high mortality rates are by products of poverty.

Poverty is one of the core challenges faced by the United Nations. In September 2015, a total of 193 countries signed a global political agreement known as Sustainable Development Goals (SDG). The core purpose of SDG is to achieve eradication of poverty in all forms without compromising on growth of economies and promoting a sustainable future for people and planet by 2030. There are 17 interconnected Sustainable Development Goals, and these goals should be implemented as a whole rather than in a fragmented manner (Le Blanc, 2015). United Nation recognizes that alleviating poverty, overcoming inequality, creating sustainable economic growth, preserving the planet, and promoting good health are linked to each other and are interdependent. The main focus of this paper is the first SDG: end poverty. While the world as a whole may be on the right path to achieve SDG-1, the current pace is much slower than what is required to achieve this ambitious goal of having less than 3 percent of world's total population living under the poverty line by 2030. Pogge and Sengupta (2015, p. 572) criticised that the SDG Agenda "does not fulfill its selfproclaimed purpose of inspiring and guiding a concerted international effort toward global development and the eradication of severe poverty".

In countries where the average income of the population and low and resources are abundant, agriculture can act as an escape route from the viscous cycle of poverty (Christiaensen et. al. 2011). Investing in the development of agricultural sector can also assist to achieve other SDG goals, namely zero hunger (SDG-2) and also life on land (SDG-15). By enhancing the agricultural productivity, a society can reduce the number of people living below the international poverty line (Christiaensen et. al., 2011; Davis et al., 2012; Irz et al., 2002). However, farmers can rarely afford to hire equipment and purchase seasonal inputs (Kaleem and Abdul Wajid, 2009) and the agricultural financing offered by conventional banking is exploitative according to Shariah principles. Ahmed et al. (2015) suggested that the underlying Shariah principles could help meeting the financial needs of the poor and Sustainable Development Goals at large. Islam has long committed to fulfill social justice obligations through economic affairs and transactions. The emphasis on risk-sharing and prohibition of speculative investment would produce a relatively stable and resilient financial system. Salam is an Islamic finance instrument mostly used in financing farmers and agricultural businesses. This mode of financing allows for advance payment of goods which provides financial security to the farmers.

Bai Salam is a sale contract that was practiced by Prophet Muhammad SAW himself. A study on the life of the Prophet (SAW) narrates incidents where he guided the companions about this distinct sale contract. Ibn Abbas narrated that the Messenger of Allah (SAW) came to Madinah, and found the inhabitants using forward (Salam) contracts in fruits for one, two, and three years. The Prophet (SAW) said: "whoever

International Journal of Management and Applied Research, 2019, Vol. 6, No. 3 
enters into a forward contract let him specify a known volume or weight, and a known term of deferment" (Hadith 2126, Bukhari). The Holy Quran also states: "O you who believe when you deal with each other in transactions involving future obligations in a fixed period put them in writing" (2:82).

Back in the days of the Prophet (SAW) when riba was declared haram, slashing out the option of interest-based loans, Salam was introduced to meet the need of small farmers who need money to grow their crops and to feed their family up to the time of harvest. Therefore, the Prophet (SAW) allowed them to sell their agricultural products in advance. Besides farmers, Salam was also used by manufacturing businesses. Like farmers, manufacturers would be able to purchase raw materials and produce goods with the advanced payments provided by buyers. Although buyers receive the goods at later date, they could purchase the goods at a price that are lower than current market price (Usmani, 1998).

This paper is divided into five sections. Followed by this introduction, section two deals with literature review, discusses the potential of Islamic Social Financial instruments to bring prosperity and eliminate poverty and section three discusses the proposed models with associated risks. Section four explores the practicability of the proposed models followed by the conclusion.

\section{The Concept of Bai Salam and Its Uses}

The core philosophy behind Islamic economic system revolves around the need for establishing a more just society. One of the foremost purposes of Shariah is to mitigate economic inequality and avoid exploitation of the financially disadvantaged groups. Islamic financial instruments, such as Bai Salam and Qard Al-Hasan, are viable alternatives for the interest-based loans as envisaged by the Islamic finance ecosystem (Obaidullah, 2015). If implemented correctly, Salam contract can help to alleviate poverty and potentially end hunger (Muneeza et. al., 2011). Bai Salam contract benefits both buyer and seller in the following ways: first, the seller is able to receive advanced payment; second, the buyer is able to purchase agricultural products at a competitive price (Kaleem and Ahmad, 2010; Muneeza et. al., 2011; Obaidullah, 2015). Kaleem and Ahmad (2010) stressed that Salam contract can be useful in reducing price volatility by locking the future price through agreements.

There are several Islamic banks and financial institutions offer Salam financing to farmers, namely microfinance providers like Muslim Aid Sri Lanka and Wasil Foundation (Obaidullah, 2015). These microfinance providers offer a variety of Shariah compliant products (e.g. Ijarah and Mudharabah) to financially disadvantaged groups in Sri Lanka and Pakistan. It is interesting to note that Dubai Islamic Bank offers Salam cum Wakala to its customers (Dubai Islamic Bank, 2018) for manufacturing and agricultural businesses. While Muslim Aid Sri Lanka and Wasil Foundation targeted on the poor and farmers, Dubai Islamic Bank also offer Salam contract to manufacturing businesses which requires advanced payment or funding to fill short-term cash-flow gaps in order to replenish inventory or business refurbishments.

International Journal of Management and Applied Research, 2019, Vol. 6, No. 3 
A number of Islamic scholars proposed the use of Salam in financing agricultural businesses with other Islamic financial instruments (Muneeza et. al., 2011) and financial technological such as crowdfunding platform (Saiti et al., 2018). Muneeza et. al., (2011) suggested to combine Wakalah (agency agreement) and Salam as a means to finance farmers. In this model, the financier pays the farmer for agricultural outputs under Salam contract and appoints farmers as agent under Wakalah contract. The bank is thus free from dealing with crops, thereby reducing operational risks. Nonetheless, the financier is not insured against natural calamity, thereby expose bank to high risk of non-delivery. On the other hand, Saiti et al. (2018) proposed the idea of combining crowdfunding and Salam to fund agricultural businesses. In this way, a potentially large sum of money can be raised from donors or investors across the globe. One major problem of this idea is that, there is no guarantee or insurance policy to safeguard the financial interests of investors.

Despite of the advantages of Salam contract, financiers seem reluctant to use Salam instrument due to high level of complexity and risk involved under this financial instrument. In a study of bankers' perception towards Salam contract, Kaleem and Ahmad (2010, p. 223) reported that vast majority of the respondents consider it as "impossible for banks to be involved in the purchase of crops" due to limited understanding regarding the working mechanism of Salam contract. Under Salam contract, buyer (or financier) take possession of the crops, and sell the agricultural products to consumers (Obaidullah, 2015). Contemporary financier or banker typically prefer to dealing with money than commodities or crops (Kaleem and Ahmad, 2010). In addition to the complexity of dealing with crops, Salam contract also exposes banks to default risk, non-performance risk, operational risk, and also natural calamity (Kaleem and Ahmad, 2010; Muneeza et. al., 2011).

In practice, financial institutions mitigate the risks that may occur in Salam using different mechanisms that are in line with Shariah principles. Muslim Aids Sri Lanka, for instance, combined the concept of Salam and Mudharabah (a profit and sharing arrangement) by financing farmers with forward sale and entering a partnership with local millers (Obaidullah, 2015). The financier in this case, Muslim Aid, does not involve in the production and sale of crops because the operation is undertaken by partnered millers. Another common risk mitigation technique is to adopt parallel Salam, where the financier enters two Salam contracts with a farmer and a third party simultaneously. Under this arrangement, the sale and delivery of the agricultural products will be done by the third party without intervention from the bank (Muneeza et. al., 2011).

\section{Proposed Models using Bai Salam}

Based on literature review, it is suggested here that United Nation could adopt this mode of financing to support the economically disadvantaged farmers in developing countries. This section proposes two models for the application of Bai Salam, specifying its operations and potential risks associated with these models.

\subsection{Centralised Model}

International Journal of Management and Applied Research, 2019, Vol. 6, No. 3 
In this model, United Nation (UN) enters two Salam contracts with Farmer Cooperative and businessmen respectively.

Figure 1: Centralised Model

\section{First Salam}

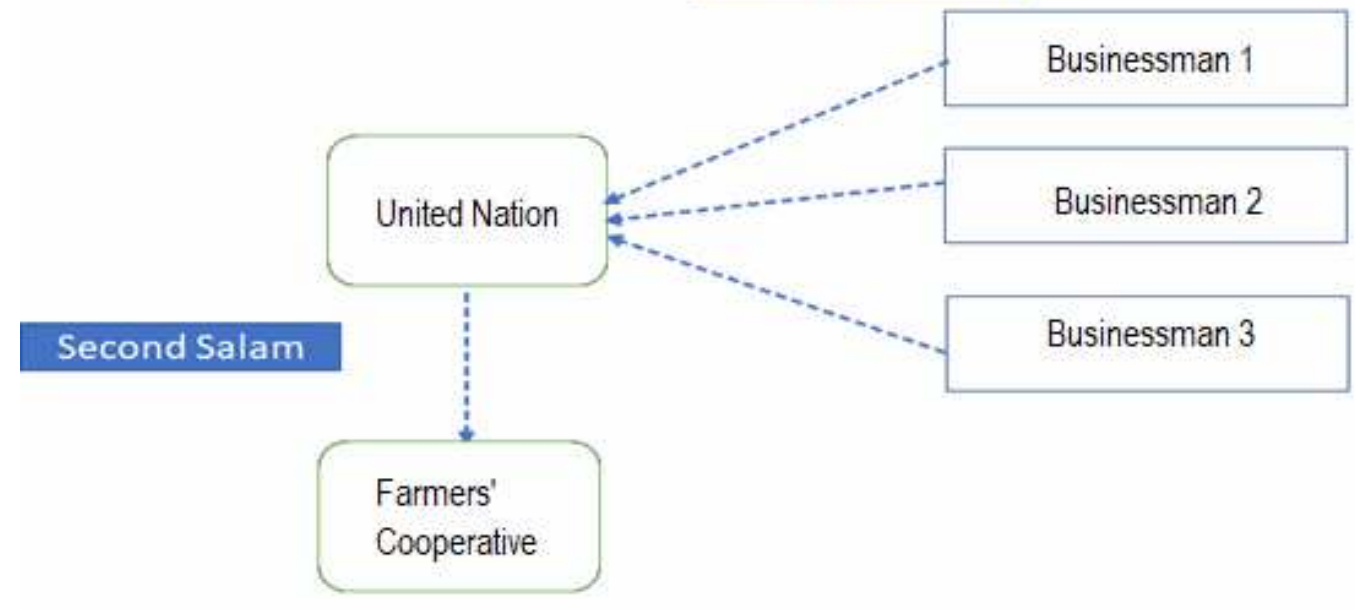

Source: Author's own

The following steps explain the operations of the centralised model:

Step 1: UN and businessman enter into the first Salam contract. In this contract, $\mathrm{UN}$ acts as a seller and the businessman acts as a buyer.

Step 2: $\quad$ Businessman will pay the agreed amount of the product in full.

Step 3: UN (buyer) enters into a parallel Salam contract with the Farmers' Cooperative (seller) and the UN pays the full amount in advance to the cooperative.

Step 4: $\quad$ At the date of maturity, farmer delivers the product to UN as agreed. To ensure that the sale is valid and complies with Shariah law, the terms and conditions must be clearly defined in order to reduce the chance for bad-faith dealings occurring. In the event of non-delivery due to unforeseeable circumstances, the seller will be held responsible to deliver the exact same product by purchasing it from other sellers or utilising cash reserve.

Step 5: The businessman receives the goods from UN following the same conditions relating to subject matter as mentioned in step 4 .

\subsubsection{Limitations}

The centralised model has five major limitations. First and foremost, it is too risky for the financier. Since the proposed model is targeted to farmers, both financier and farmers face the risk of non-delivery or late delivery due to natural calamity. The farmer may not be able to deliver the product on time or meet the standards as agreed. One possible risk mitigation solution is to set up an emergency fund or cash reserve to

International Journal of Management and Applied Research, 2019, Vol. 6, No. 3 
meet the unanticipated losses. In this way, the farmers could utilise the cash reserve in the event of non-delivery due to adverse weather conditions.

Second, the centralised model puts UN at the spot light. The idea of using Bai Salam to alleviate poverty may not be attractive for UN due to the risky nature of agricultural businesses and excessive administrative burden. The default risk is particular high in deprived areas due to inability to repay (Kodongo and Kendi, 2013) and fulfil the contractual obligation (Milne, 1976). Furthermore, the UN may be in favour of using their tried and tested methods to alleviate poverty instead of adopting an unfamiliar approach. A solution to this is to engage Islamic financial institutions in designing a Shariah-compliant agricultural financing, especially for Muslims majority countries.

Third, some countries may not agree with the interference or supervision of UN. Some nations may see financial assistance outside the country as a threat than an opportunity in promoting socio-economic development. Such prejudice is based on the view that "debt trap" diplomacy leads to a vicious cycle of debts (Behuria, 2018), despite it brings economic growth in the beginning.

Fourth, laws and regulation in each continent are different, which pose regulatory challenges in order to implement Salam centralised model at global scale. It not only needs to complement with civil and commons laws, but also banking laws in different countries.

Last but not least, the centralised model may pose cultural barriers to all stakeholders. Non-Muslims may not comprehend Shariah principles and violate them unintentionally. An understanding of Islamic financial instruments is central to the successful implementation of this model.

\subsection{Decentralised Model}

The second model is a decentralised model which combines the use of Wakalah and Salam. In this model, UN appoints a third party as agent to manage the overall operations in order to mitigate sovereignty, legal, and cultural risks. The following steps describe how this model works.

Step 1: UN enters into Wakalah agreement with its daughter organizations in each country for instance United Nation Farmer Cooperative Malaysia in Malaysia.

Step 2: The daughter organization enters into a Salam contract with the Farmers' Cooperative.

Step 3: The daughter organization makes full payment in advance to Farmers' Cooperative.

Step 4: The daughter organization enters into a parallel Salam contract with a businessman or middleman.

Step 5: $\quad$ Businessman pays the down payment as a promise to buy the product.

International Journal of Management and Applied Research, 2019, Vol. 6, No. 3 
Step 6: Farmers' Cooperative delivers the products to UN daughter organizations on the agreed date. To ensure that the contact is valid, the terms and conditions must be clearly defined and agreed at the time of signing up the contract. The seller is responsible to deliver goods on time; in the event of non-delivery, the seller can either purchase goods from other seller or utilise cash reserve.

Step 7: The UN delivers the goods to the business following the same conditions of subject matter as described in the previous step.

Step 8: $\quad$ The UN pays Wakalah fee to its daughter organization.

Figure 2: Decentralised Model

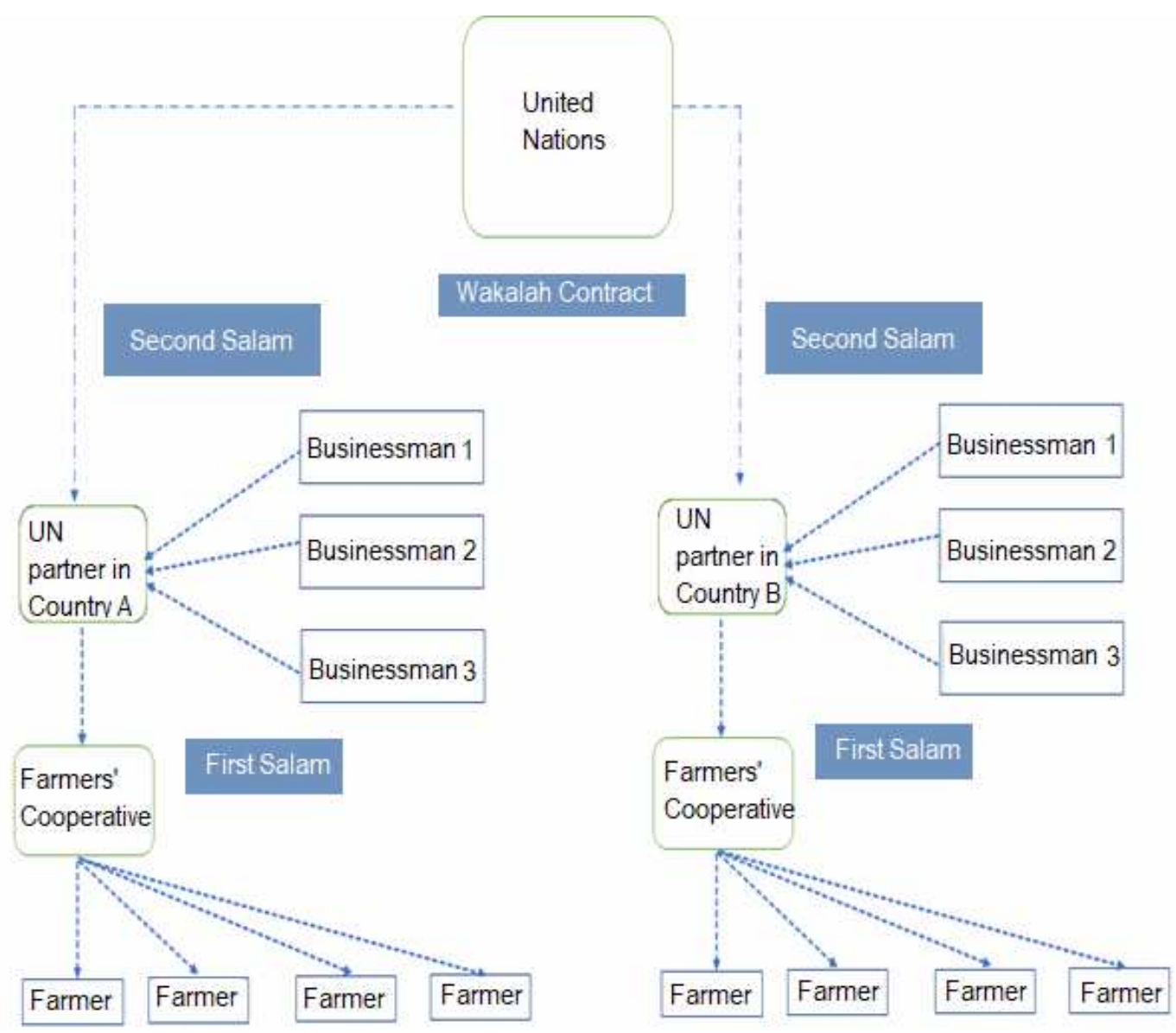

Source: Author's own

\subsubsection{Limitations}

There are three main limitations in this decentralised model. First, agriculture is a timeconsuming process and thus the economic outcomes of this model will not be immediate. It is difficult to assume the total time needed for an agricultural business to make a profit, especially at such global scale.

International Journal of Management and Applied Research, 2019, Vol. 6, No. 3 
Second, this model may give rise to risk of corruption due to sizeable funds involved in this model. One possible solution to mitigate corruption risk is to adopt blockchain technology which enables regulator to monitor flows of fund (Muneeza et al., 2018).

Third, the decentralised model will require a strong governance framework, and strong collaboration and coordination among UN headquarters, regions, country offices, in addition to local authorities, non-governmental organisations, and other civil society actors. Such scale of international collaboration requires global commitment and engagement. A poor coordination or preferential treatment may upset a potential partner, thus leading to a break up of collaboration.

\section{Decentralised Model vs. Cash Assistance Programme}

The proposed decentralised model can be tested by partnering with United Nations High Commissioner for Refugees (UNHCR) which focuses on helping the refugees to elevate their living standards. UNHCR Malaysia is an UN subsidiary that aims to protect the refugees and to provide necessities like clean water, sanitation, healthcare, food etc. One of their programs is to provide financial assistance to the refugees. UNHCR has a Cash Assistance Program (CAP) dedicating to refugees. However, the cash assistance program is not a viable long-term solution for refugees seeking financial stability and independency. UNHCR requires a more durable solution to accommodate the growing refugee population (Cunliffe, 1995). Over time, long term reliance on cash assistance may elicit dependency behaviour. It is therefore suggested here a hybrid model of Salam and Wakalah for UNHCR in helping refugees.

Figure 3: Decentralised Wakalah-Salam Model

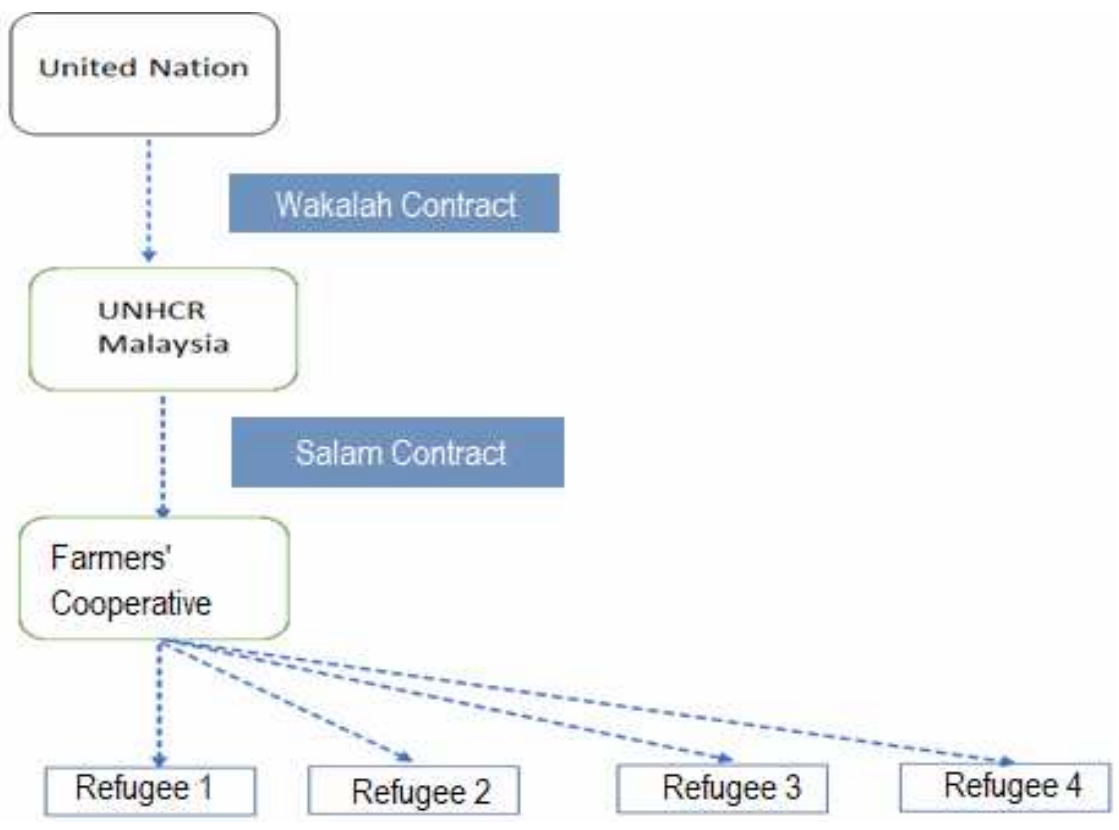

Source: Author's own

International Journal of Management and Applied Research, 2019, Vol. 6, No. 3 
The diagram above illustrates the flow of Bai Salam adopted by UN and UNHCR. Following steps explains the model in detail.

Step 1: $\quad$ UN appoints UNHCR in Malaysia to act as an agency to improve living the living standard of people and refugees in Malaysia. UNHCR will receive a fee from the UN and the purpose of this agency agreement is to achieve SDG's by replacing the Cash Assistance Program with a more sustainable solution of training and educating the people and refugees for farming.

Step 2: $\quad$ UNHCR enters into a Salam contract with the Farmers' Cooperative. The farmers' cooperative, in this case, is a group of refugees living in Malaysia who are trained and educated in farming as per the standards of UN.

Step 3: $\quad$ UNHCR pays for agricultural outputs in full and agrees on a date and place for the delivery of the product.

Step 4: $\quad$ Farmers' Cooperative deliver the agricultural output as agreed.

Note: $\quad$ The role of a businessman is not applicable in the case of Malaysia as UNHCR already have a Cash Assistance Program. For countries where the Cash Assistance Program is not present, the funds can be collected from a businessman and the previous model should be applied.

There are several benefits for using this model. Firstly, this model can serve as a way of reducing the dependency of the poor on a charitable fund and providing them with an escape route from the viscous cycle of poverty. With the help of this model, underprivileged people can set up a sustainable and profitable business which can be extended if more effort in put in. Secondly, the agricultural outputs can be sold and consumed and thus fulfilling UN's SDG 1 and 2. Thirdly, this model could contribute positively in the real GDP growth and promote new job creation. The table below summarizes differences between CAP and proposed Wakalah-Salam model.

Table 1: Comparison between CAP and Wakalah-Salam Model

\begin{tabular}{lcc}
\hline Characteristic & Current UNHCR CAP & $\begin{array}{c}\text { UNHCR while Adopting this } \\
\text { Model }\end{array}$ \\
\hline Unrestricted Cash & Yes & $\begin{array}{c}\text { No, instead they will get salary } \\
\text { based on they work }\end{array}$ \\
$\begin{array}{l}\text { Financial } \\
\text { Sustainability }\end{array}$ & $\begin{array}{c}\text { No. This model increases } \\
\text { their dependency on } \\
\text { charity. }\end{array}$ & $\begin{array}{c}\text { Yes. Their skills will increase } \\
\text { over time which will result in } \\
\text { more salaries thus promoting a } \\
\text { sustainable living. }\end{array}$ \\
& No & $\begin{array}{c}\text { Yes. UNHCR can provide } \\
\text { training to increase their skill } \\
\text { skill Building }\end{array}$ \\
& & $\begin{array}{c}\text { set avail other employment } \\
\text { opportunities. }\end{array}$
\end{tabular}

International Journal of Management and Applied Research, 2019, Vol. 6, No. 3 


\begin{tabular}{lcc} 
Job Creation & \multicolumn{1}{c}{ No } & Yes \\
Economic Growth & $\begin{array}{c}\text { Yes, but limited to the } \\
\text { purchasing power only }\end{array}$ & $\begin{array}{c}\text { Yes, to the extent of increasing } \\
\text { GDP and employment rate }\end{array}$ \\
Achieving SDGs & $\begin{array}{c}\text { Only one SDG is } \\
\text { achieved (Zero Hunger) } \\
\text { for a short term }\end{array}$ & $\begin{array}{c}\text { At least two SDGs can be } \\
\text { achieved (end poverty and zero } \\
\text { hunger) for a longer term. }\end{array}$
\end{tabular}

Source: Author's own

\section{Conclusion}

This paper explores the use of Bai Salam as agricultural financing in achieving Sustainable Development Goals set by the United Nation. Based on a literature review on Bai Salam contract, this paper found that this mode of financing is often overlooked by Islamic financial institutions because not many Islamic financiers are aware of Bai Salam; those who are aware of Bai Salam perceive the risks involved in this mode of financing is too risky for financiers. Because of these reasons, many financiers offer this mode of financing. Therefore, this paper proposes two models of Bai Salam as alternative financing for farmers and intermediaries in Muslim majority countries. It is hoped that the proposed models could help to change the perceptions of financiers and adopt these models for greater good.

The proposed models aim to take benefit of the risk sharing nature of the contract, combined with the benevolence of the global social organizations to propose a sustainable solution to poverty. Like forward sale contract, Salam contract reduces the risk of future price volatility (Muneeza et. al., 2011) and enhance market liquidity (Kaleem and Ahmad, 2010). The proposed models have the potential to improve socioeconomical activities for the financially disadvantaged groups, thereby help to achieve SDG 1 and 2, end poverty and hunger. However, further research is needed in order to assess the social value of Bai Salam contracts to justify the use of Salam contracts in developing countries.

\section{References}

1. Ahmed, H., Mohieldin, M., Verbeek, J. and Aboulmagd, F. W. (2015), On the sustainable development goals and the role of Islamic finance: Policy Research working paper no. WPS 7266, Washington, D.C.: World Bank Group. [Online] Available from:

http://documents.worldbank.org/curated/en/442091467999969424/On-thesustainable-development-goals-and-the-role-of-Islamic-finance [Accessed on 2 June 2019].

2. Behuria, A. K. (2018), "How Sri Lanka Walked into a Debt Trap, and the Way Out", Strategic Analysis, Vol. 42, No. 2, pp. 168-178. https://doi.org/10.1080/09700161.2018.1439327

International Journal of Management and Applied Research, 2019, Vol. 6, No. 3 
3. Christiaensen, L., Demery, L. and Kuhl, J. (2011), "The (evolving) role of agriculture in poverty reduction-An empirical perspective", Journal of development economics, Vol. 96, No. 2, pp. 239-254. https://doi.org/10.1016/j.jdeveco.2010.10.006

4. Cunliffe, A. (1995), "The Refugee Crises: a Study of the United Nations High Commission for Refugees", Political Studies, Vol. 43, No. 2, pp. 278-290. https://doi.org/10.1111/j.1467-9248.1995.tb01712.x

5. Davis, K. E.; Nkonya E.; Kato D. A.; Mekonnen A.; Odendo M.; Miiro R. and Nkuba J. (2012), "Impact of Farmer Field Schools on Agricultural Productivity and Poverty in East Africa", World Development, Vol. 40, No. 2, pp. 402-413. https://doi.org/10.1016/j.worlddev.2011.05.019

6. Dubai Islamic Bank (2018), Financing for Working Capital - Manufacturing, [Online] Available from: https://www.dibpak.com/index.php/smebanking/business-short-term-products/ [accessed on 2 June 2019].

7. Irz X.; Lin L.; Thirtle C. and Wiggins, S. (2002), "Agricultural Productivity Growth and Poverty Alleviation", Development Policy Review, Vol. 19, No. 4, pp. 449-466. https://doi.org/10.1111/1467-7679.00144

8. Kaleem, A. and Abdul Wajid, R. (2009), "Application of Islamic banking instrument (Bai Salam) for agriculture financing in Pakistan", British Food Journal, Vol. 111, No. 3, pp. 275-292. https://doi.org/10.1108/00070700910941471

9. Kaleem A. and Ahmad S. (2010), "Bankers' Perception towards Bai Salam Method for Agriculture Financing in Pakistan", Journal of Financial Services Marketing, Vol. 15, 3, 215 - 227. https://doi.org/10.1057/fsm.2010.18

10. Kodongo, O. and Kendi, L. G. (2013), "Individual lending versus group lending: An evaluation with Kenya's microfinance data", Review of Development Finance, Vol. 3, No. 2, pp. 99-108

11. Le Blanc, D (2015), “Towards Integration at Last? The Sustainable Development Goals as a Network of Targets", Sustainable Development, Vol. 23, No. 3, pp. 176- 187. https://doi.org/10.1002/sd.1582

12. Milne, F. (1976), "Default Risk in a General Equilibrium Asset Economy with Incomplete Markets", International Economic Review, Vol. 17, No. 3, pp. 613-625

13. Mohammad Bin Ismail, Sahih Bukhari, Kitaab us Salam, Bab us Salam fi wazanal maloom, vol. 2, Hadith 2126.

14. Muneeza, A., Nurul Atiqah Nik Yusuf, N. and Hassan, R. (2011), "The possibility of application of salam in Malaysian Islamic banking system”, Humanomics, Vol. 27, No. 2, pp. 138-147. https://doi.org/10.1108/08288661111135135

International Journal of Management and Applied Research, 2019, Vol. 6, No. 3 
15. Muneeza, A.; Arshad, N. A. and Arifin, A. T. (2018), "The Application of Blockchain Technology in Crowdfunding: Towards Financial Inclusion via Technology", International Journal of Management and Applied Research, Vol. 5, No. 2, pp. 82-98. https://doi.org/10.18646/2056.52.18-007

16. Obaidullah, M. (2015), "Enhancing food security with Islamic microfinance: insights from some recent experiments", Agricultural Finance Review, Vol. 75 No. 2, pp. 142-168. https://doi.org/10.1108/AFR-11-2014-0033

17. Pogge, T. and Sengupta M. (2015), "The Sustainable Development Goals (SDGS) as drafted: Nice idea, poor execution", Washington International Law Journal, Vol. 24, No. 3, pp. 571-587.

18. Saiti, B., Afghan, M. and Noordin, N. (2018), "Financing agricultural activities in Afghanistan: a proposed salam-based crowdfunding structure", ISRA International Journal of Islamic Finance, Vol. 10 No. 1, pp. 52-61. https://doi.org/10.1108/IJIF09-2017-0029

19. United Nations (No Date), Goal 1: End poverty in all its forms everywhere, [Online] available from: https://www.un.org/sustainabledevelopment/poverty/ [accessed on 1 June 2019].

20. Usmani, M. M. T. (1998), An Introduction to Islamic Finance. Karachi: Idaratul Ma'arif. 